\title{
Anti-senescence ion-delivering nanocarrier for recovering therapeutic properties of long-term-cultured human adipose-derived stem cells
}

Yeong Hwan Kim ${ }^{1 \dagger}$, Gwang-Bum Im ${ }^{1 \dagger}$, Sung-Won Kim', Yu-Jin Kim', Taekyung Yu², Ju-Ro Lee ${ }^{3}$, Soong Ho Um', Yoon Ki Joung ${ }^{3,4}$ and Suk Ho Bhang ${ }^{1 *}$ (i)

\begin{abstract}
Background: Human adipose-derived stem cells (hADSCs) have been used in various fields of tissue engineering because of their promising therapeutic efficacy. However, the stemness of hADSCs cannot be maintained for long durations, and their therapeutic cellular functions, such as paracrine factor secretion decrease during long-term cell culture. To facilitate the use of long-term-cultured hADSCs (L-ADSCS), we designed a novel therapeutic anti-senescence ion-delivering nanocarrier (AIN) that is capable of recovering the therapeutic properties of L-ADSCs. In the present study, we introduced a low-pH-responsive ion nanocarrier capable of delivering transition metal ions that can enhance angiogenic paracrine factor secretion from L-ADSCs. The AINs were delivered to L-ADSCs in an intracellular manner through endocytosis.
\end{abstract}

Results: Low pH conditions within the endosomes induced the release of transition metal ions (Fe) into the L-ADSCs that in turn caused a mild elevation in the levels of reactive oxygen species (ROS). This mild elevation in ROS levels induced a downregulation of senescence-related gene expression and an upregulation of stemness-related gene expression. The angiogenic paracrine factor secretion from L-ADSCs was significantly enhanced, and this was evidenced by the observed therapeutic efficacy in response to treatment of a wound-closing mouse model with conditioned medium obtained from AIN-treated L-ADSCs that was similar to that observed in response to treatment with short-term-cultured adipose-derived stem cells.

Conclusions: This study suggests a novel method and strategy for cell-based tissue regeneration that can overcome the limitations of the low stemness and therapeutic efficacy of stem cells that occurs during long-term cell culture.

Keywords: Angiogenesis, Functionality restoring, Intracellular ion delivery, Ischemic disease, Senescence, Stem cell therapy

\footnotetext{
*Correspondence: sukhobhang@skku.edu

${ }^{\dagger}$ Yeong Hwan Kim and Gwang-Bum Im contributed equally to this work

1 School of Chemical Engineering, Sungkyunkwan University,

Suwon 440-746, Republic of Korea

Full list of author information is available at the end of the article
}

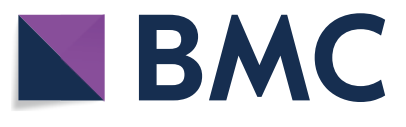

(c) The Author(s) 2021. Open Access This article is licensed under a Creative Commons Attribution 4.0 International License, which permits use, sharing, adaptation, distribution and reproduction in any medium or format, as long as you give appropriate credit to the original author(s) and the source, provide a link to the Creative Commons licence, and indicate if changes were made. The images or other third party material in this article are included in the article's Creative Commons licence, unless indicated otherwise in a credit line to the material. If material is not included in the article's Creative Commons licence and your intended use is not permitted by statutory regulation or exceeds the permitted use, you will need to obtain permission directly from the copyright holder. To view a copy of this licence, visit http://creativecommons.org/licenses/by/4.0/. The Creative Commons Public Domain Dedication waiver (http://creativeco mmons.org/publicdomain/zero/1.0/) applies to the data made available in this article, unless otherwise stated in a credit line to the data. 


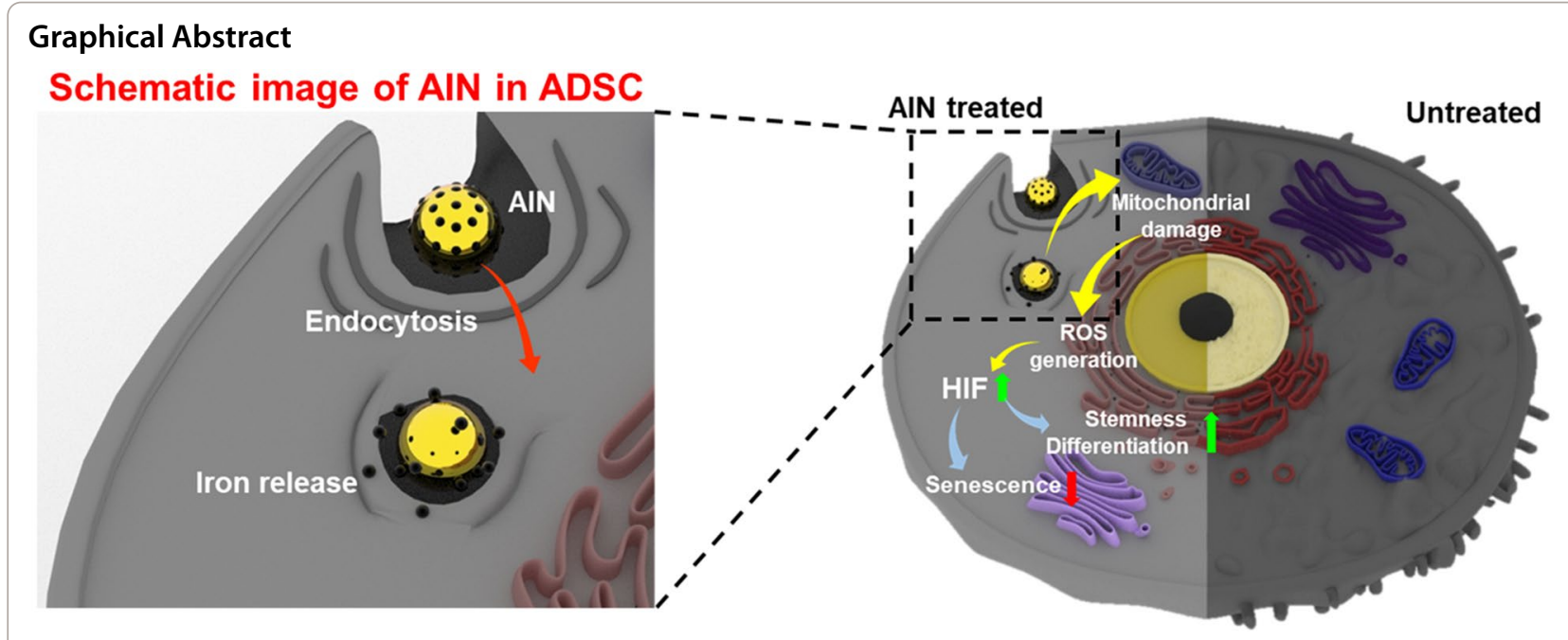

Functionality-restoring effects of AINs
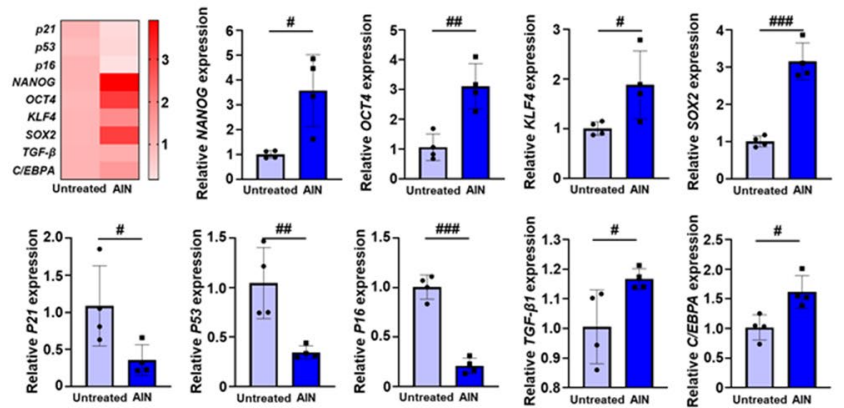

\section{Enhanced therapeutic efficacy of AINs}
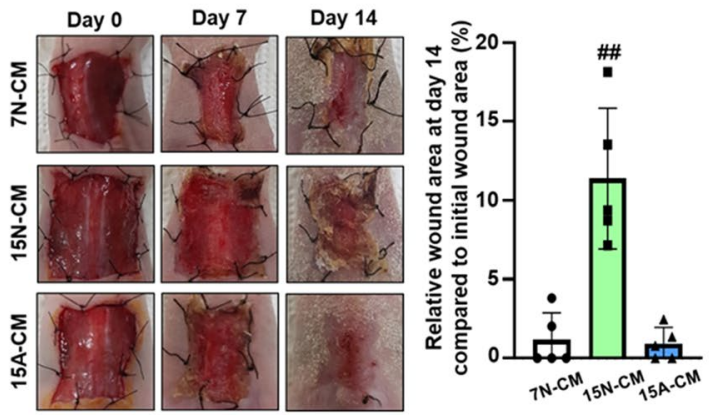

\section{Background}

Transition metal-based nanoparticles have been widely studied for use in biomedical applications, such as hyperthermic therapy, drug delivery, and bio-imaging $[1,2]$. These nanoparticles have also been applied to stem cells to improve their therapeutic efficacy [3]. Iron $(\mathrm{Fe})$, the representative element of transition metal, has been used to improve the therapeutic effect of stem cell based therapies [4-6]. Despite of its great therapeutic effect, Fe cannot be used in clinical trials due to of its potential toxicity such as ferroptosis. Ferroptosis is a result of iron-dependent oxidative cellular damage, and it can cause neurodegeneration $[7,8]$. To utilize the effect of transition metals on the therapeutic efficacy of stem cells without damage, there is a need to accurately control the treatment concentration. In this study, to prohibit the cellular damages such as ferroptosis $[9,10]$ and enhance the therapeutic effect on stem cells, we first optimized the concentration of Fe for cell treatment and then evaluated the cellular functions.

Stem cell-based therapy has been highlighted as a regenerative medicine approach for vascular diseases
[11, 12]. In particular, human adipose-derived stem cells (hADSCs) serve as attractive tools for vascularization and skin regeneration because of their convenient management, ability to differentiate into various cell-types, and secretion of angiogenic factors, such as vascular endothelial growth factor (VEGF), fibroblast growth factor (FGF), and hepatocyte growth factor [13-15]. Despite the therapeutic and differentiation ability of ADSCs, a limited number of clinical trials have been performed using ADSCs because of their short lifespan, quantitative limitations for cell transplantation, and required use at low passage numbers $[16,17]$. Cell-free conditioned media (CM) is retrieved from cultured cells and can be used to overcome the aforementioned obstacles. Recently, multiple studies have investigated the validity of the wound-healing effects of cell-free CM [18, 19]. However, long-termcultured ADSCs (L-ADCSs) secrete low concentrations of angiogenic cytokines, and this makes it difficult to use them as an alternative to short-term-cultured hADSCs (S-ADSCs) in the context of CM application. 
Herein, we developed a novel and simple anti-senescence ion-delivering nanocarrier (AIN) and an ironincorporated gold nanoparticle (AuNP) to enhance the therapeutic efficacy of CM from L-ADSCs. AuNP is well known as non-cytotoxic and stable material and used for bio-imaging material due to their surface plasmon resonance [20]. Only iron ions are released from AINs under the low $\mathrm{pH}$ conditions present in late endosomes [21] due to the difference in the reduction potentials of gold and iron [22, 23]. Iron reacts with hydrogen ions and is ionized under the acidic conditions present in late endosomes, while Au remains intact. Iron has been reported to enhance the angiogenic therapeutic efficacy of stem cells by upregulating the expression of the hypoxia-inducible factor (HIF) gene that is associated with mitochondrial reactive oxygen species (ROS) [24, 25]. Excessive intracellular ROS levels cause the initiation of programmed cell death [26]; however, mild ROS production induces the upregulation of angiogenic paracrine factor secretion and delays cellular senescence by downregulating senescence-associated gene expression [27-30].

The AINs used in this study can deliver an appropriate quantity of iron ions to hADSCs, thus resulting in no induction of apoptosis in these cells. As a result, iron ions released from the AINs within endosomes generate mild ROS levels, upregulate HIF expression, enhance angiogenic therapeutic efficacy, and reverse the senescence of L-ADSCs. This provides meaningful potency to allow for the therapeutic usage of L-ADSCs that until now were considered to be of no use for stem cell therapy. This anti-senescence strategy may expand the biomedical field by allowing for further utilization of stem cell-based therapies.

\section{Results and discussion}

Senescent cells are considered to be bio-waste for stem cell therapy due to their reduced therapeutic efficacy, reduced differentiation ability, and the risk of mutation [31-33]. Strategies for the restoration of the functionality of stem cells, including extracellular modifications and cell reprogramming, have been widely researched [34-37]. However, extracellular modifications are costly and can be time-/labor-consuming and involve complex processes. Also, several studies aimed to overcome the senescence and restore cellular functionality of stem cells using biomaterials have been reported [38-40]. In previous studies, most of biomaterials acted as carriers of genes or drugs. Therefore, additional processes for enhancing gene or drug delivery efficiency were required. Additionally, non-degradable property of biomaterials that can induce materials accumulation in body remained as a problem to be solved. In this study, we used transition metal-based nanoparticle as a therapeutic agent. We designed the nanoparticle to undergo degradation depends on low $\mathrm{pH}$ condition. In this study, we developed a safe and simple nanocarrier to restore the functionality of senescent hADSCs. Intracellularly delivered AINs release iron ions in L-ADSCs due to the acidic conditions present in the exosomes, and this release generates mild levels of ROS (Additional file 1: Fig. S1). As a result, the generated mild levels of ROS facilitate a reduction in cellular senescence and restore the functionality of L-ADSCs.

\section{Characterization of AINs}

The transmission electron microscopy (TEM) image of the AINs revealed a spherical shape possessing an average diameter of $3.57 \pm 0.6 \mathrm{~nm}$ (Fig. 1A and B). Energydispersive X-ray spectroscopy (EDXS) analysis indicated that the AINs consisted of iron and gold (Fig. 1C). A slight peak movement (blue squares) was detected due to the different sizes of the gold and iron ions based on powder X-ray diffraction (XRD) patterns (Fig. 1D). The ultraviolet/visible (UV-Vis) spectrum peak of the AINs at $\mathrm{pH}$ 7.0, was observed at $505 \mathrm{~nm}$ according to plasmon resonance, while those of AuNPs and AINs at $\mathrm{pH}$ 4.5 were observed at $529 \mathrm{~nm}$ and $530 \mathrm{~nm}$ according to plasmon resonance, respectively. This demonstrates that the presence of iron causes a red shift (Fig. 1E) [41]. The atomic ratio alteration of AINs under acidic $(\mathrm{pH} 4.5)$ and standard ( $\mathrm{pH} 7.0)$ conditions are presented in Fig. 1F. No significant difference was observed in the atomic ratio (gold/iron) at $\mathrm{pH} 7.0$ compared to that under standard conditions (gold/iron $=2.4$ ), while the same ratio was markedly increased under acidic conditions. The atomic ratio alteration of AINs in response to different $\mathrm{pH}$ conditions highlights the potency of AINs in regard to serving as intracellular metal ion carriers to stem cells.

\section{Optimizing the concentration and treatment time of AINs}

To optimize the concentration of AINs used for L-ADSC treatment, at cell viability assay was performed in a 24-well cell culture dish using Cell Counting Kit-8 (CCK8 ) to verify the cytotoxicity of AINs after treatment for 24 h (Fig. 2 A). AINs exhibited no cytotoxicity up to a concentration of $3 \mu \mathrm{g} / \mathrm{mL}$ of AINs; however, the cytotoxicity was significantly increased at AIN concentrations of greater than $4 \mu \mathrm{g} / \mathrm{mL}$. Similar to the results of the CCK-8 assay, treatments with $5 \mu \mathrm{g} / \mathrm{mL}$ of AINs induced cell death in L-ADSCs, and at a concentration of $3 \mu \mathrm{g} /$ $\mathrm{mL}$, AINs exerted no harmful effects on the cell viability of L-ADSCs according to the results of the terminal deoxynucleotidyl transferase-mediated dUTP nick end labeling (TUNEL) assay (Fig. 2B) and the fluorescein diacetate/ethidium bromide (FDA/EB) staining analysis 

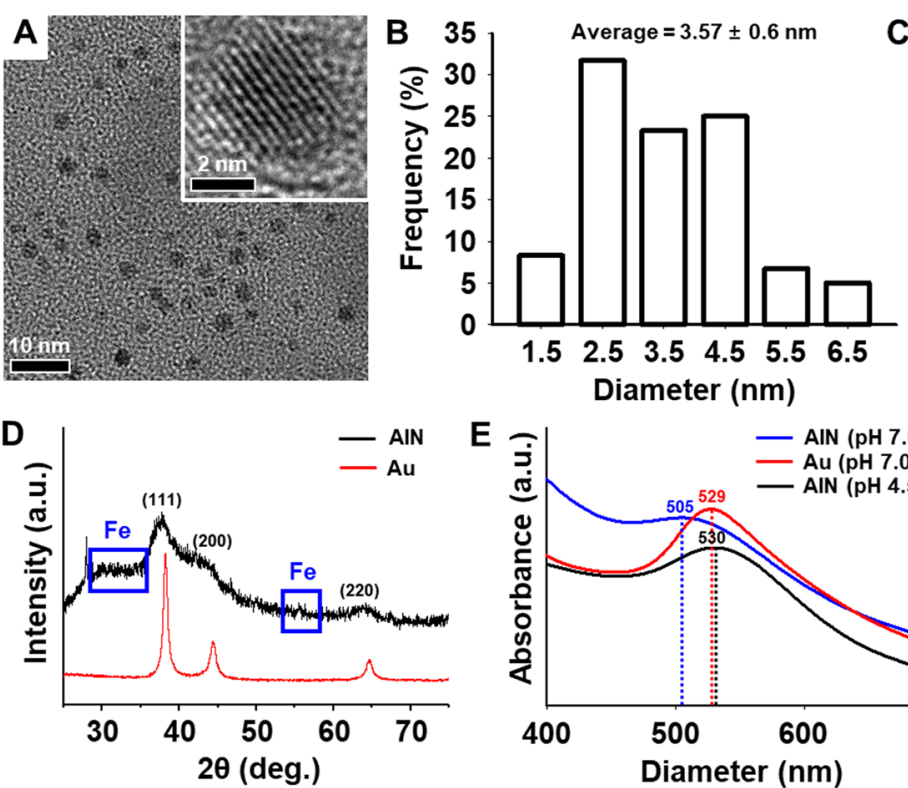

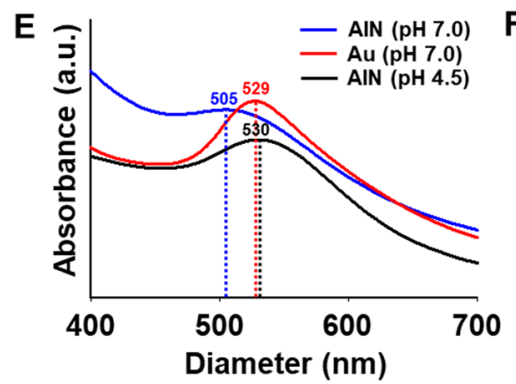

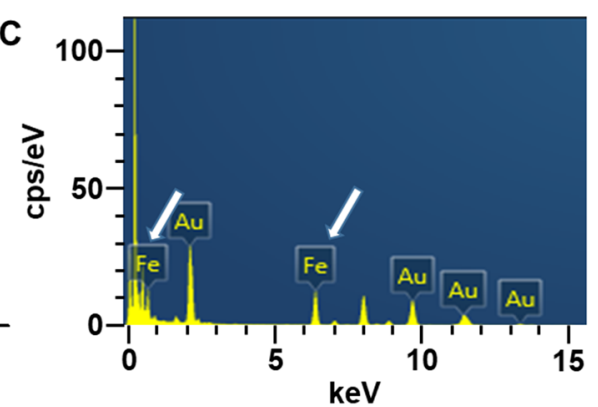

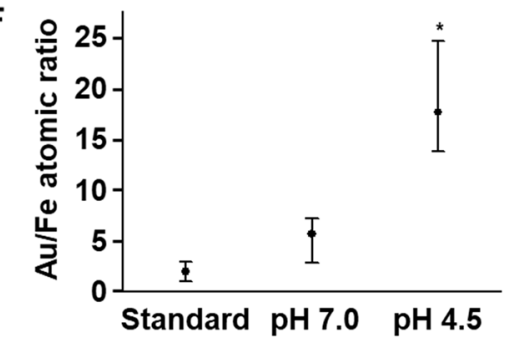

Fig. 1 Physical and chemical properties of anti-senescence ion-delivering nanocarriers (AINs). A A transmission electron microscopy (TEM) image of AINs (high power magnification at the top-left corner). B Size distribution of AINs, as measured using TEM. C Energy-dispersive X-ray spectroscopy (EDXS) analysis of AINs. Iron atom peaks are indicated with white arrows. D X-ray diffraction (XRD) patterns of AINs. Iron ion patterns are emphasized using blue squares. E Ultraviolet-visible spectroscopy (UV-Vis) spectra of AINs at pH 7.0 (blue line), gold nanoparticles (Au) at pH 7.0 (red line), and AINs at pH 4.5 (black line). Peak shifts owing to the present of iron. $\mathbf{F}$ The component gold/iron ratio profile of AINs as estimated using EDXS under the different $\mathrm{pH}$ conditions at $12 \mathrm{~h}\left(\mathrm{n}=3,{ }^{*} \mathrm{p}<0.05\right.$ versus standard group)

(Fig. 2C). In response to treatment with $5 \mu \mathrm{g} / \mathrm{mL}$ of AINs, L-ADSCs changed morphologically and shrunk in size compared to the characteristics the other groups, thus indicating that a high dose of AINs induced cell apoptosis (Fig. 2D). As presented in Fig. 2E, we measured the expression of angiogenic genes, including $V E G F$ and $F G F 2$, in L-ADSCs at various time-points post-treatment with $0,1,2$, and $3 \mu \mathrm{g} / \mathrm{mL}$ of AINs (Fig. 2E). The gene expression levels of $V E G F$ and FGF2 in L-ADSCs were highest at $12 \mathrm{~h}$ when the cells were treated with $3 \mu \mathrm{g} / \mathrm{mL}$ of AINs. Apoptosis-related genes, including $B A X$ and $C A S P A S E 3$, were significantly upregulated in L-ADSCs that were treated with $5 \mu \mathrm{g} / \mathrm{mL}$ of AINs (Fig. 2F). Additionally, the proliferation-related genes KI-67 and PCNA were significantly downregulated in L-ADSCs that were treated with $5 \mu \mathrm{g} / \mathrm{mL}$ of AINs (Fig. 2G). However, there was no significant difference in the expression levels of both cell apoptosis-related and proliferation-related genes between cells treated with 0 and $3 \mu \mathrm{g} / \mathrm{mL}$ of AINs.

\section{Functionality-restoring effects of AINs}

The AINs treated the cells can be delivered to intracellular domain through endocytosis. Afterward, the AINs release Fe ions due to low $\mathrm{pH}$ condition of endosome. Released Fe ions induce mild ROS generation through affecting mitochondria which results HIF gene expression. The treatments with AINs induced the upregulation of stemness- and differentiation-related gene expression levels along with a downregulation of senescence-relate gene expression in L-ADSCs (Fig. 3A). To investigate the cellular uptake process for AINs, we observed the cytoplasm of L-ADSCs using TEM (Fig. 3B and Additional file 1: Fig. S2). Twelve hours after treatment, AINs were observed within the endosomes of L-ADSCs. To quantify the amount of AINs within the L-ADSCs, the cells were analyzed using an inductively coupled plasma optical emission spectrometer (ICPOES) (Fig. 3C). Based on this analysis, $5.19 \pm 0.33 \mu \mathrm{g}$ of iron was detected in the L-ADSCs. Additionally, the amounts of iron ions in CM harvested from L-ADSCs at passage 15 without AIN treatment (15 N-CM) and from L-ADSCs at passage 15 with AIN treatment (15 A-CM) were analyzed (Fig. 3D). We observed that the majority of the AINs were retained within L-ADSCs, and based on this observation, we did not focus extensively on the possible iron effect during CM treatment at the wound site. In particular, the heat map image revealed downregulation of senescence-related gene expression and upregulation of stemness- and differentiation-related gene expression in AIN-treated L-ADSCs compared to the expression levels in untreated L-ADSCs (Fig. 3E). AINs treatment significantly decreased the gene expression 


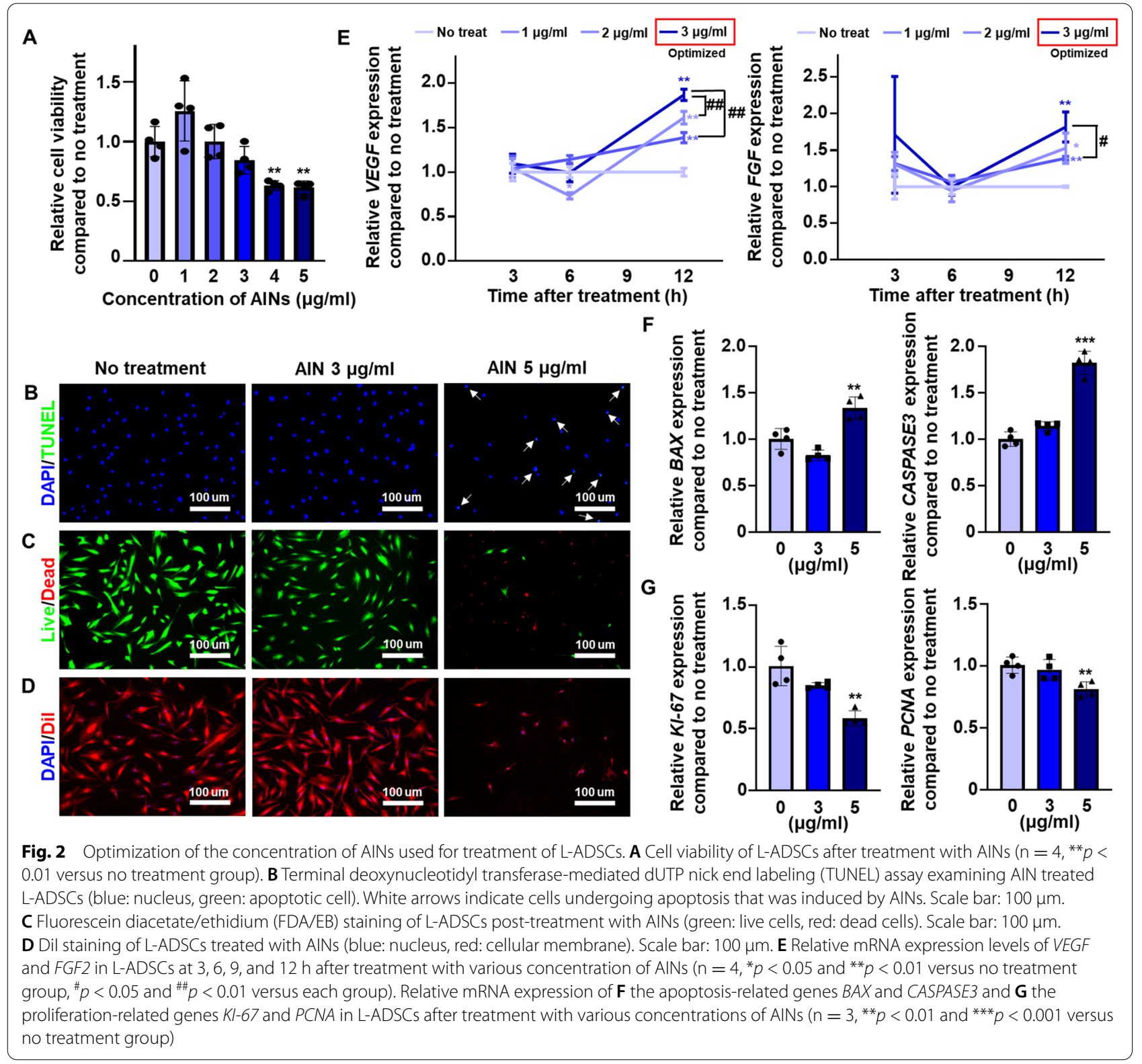

of senescence-related markers, including $P 16, P 21$, and $P 53$, and increased the gene expression of the stemnessrelated markers NANOG, OCT4, KLF4, and SOX2 as evaluated using quantitative reverse transcription polymerase chain reaction (qRT-PCR) analyses (Fig. 3F and G). As mentioned earlier, senescence- and stemnessrelated genes are regulated by HIF. HIF has also been reported to regulate the expression of several differentiation-related genes $[42,43]$. The expression levels of differentiation-related genes, including transforming growth factor-beta 1 (TGF- $\beta 1$ ) and CCAAT/enhancer-binding protein $\alpha(\mathrm{C} / \mathrm{EBPA})$ the function as chondrogenesis and adipogenesis factors, respectively, were increased in
L-ADSCs that were treated with AINs compared to the levels in untreated L-ADSCs (Fig. $3 \mathrm{H}$ ). Upon treatment, the AINs were successfully delivered to the intracellular domain of L-ADSCs without any detectable extracellular leakage of iron, and these AINs exhibited showed meaningful senescence-overcoming potency by downregulating senescence-related gene expression and upregulating stemness- and differentiation-related gene expression.

\section{Restoration of angiogenic functionality by AINs}

To quantify the angiogenic paracrine factor secretion from L-ADSCs post-AINs treatment, VEGF and FGF2, both of which are representative angiogenic factors, 


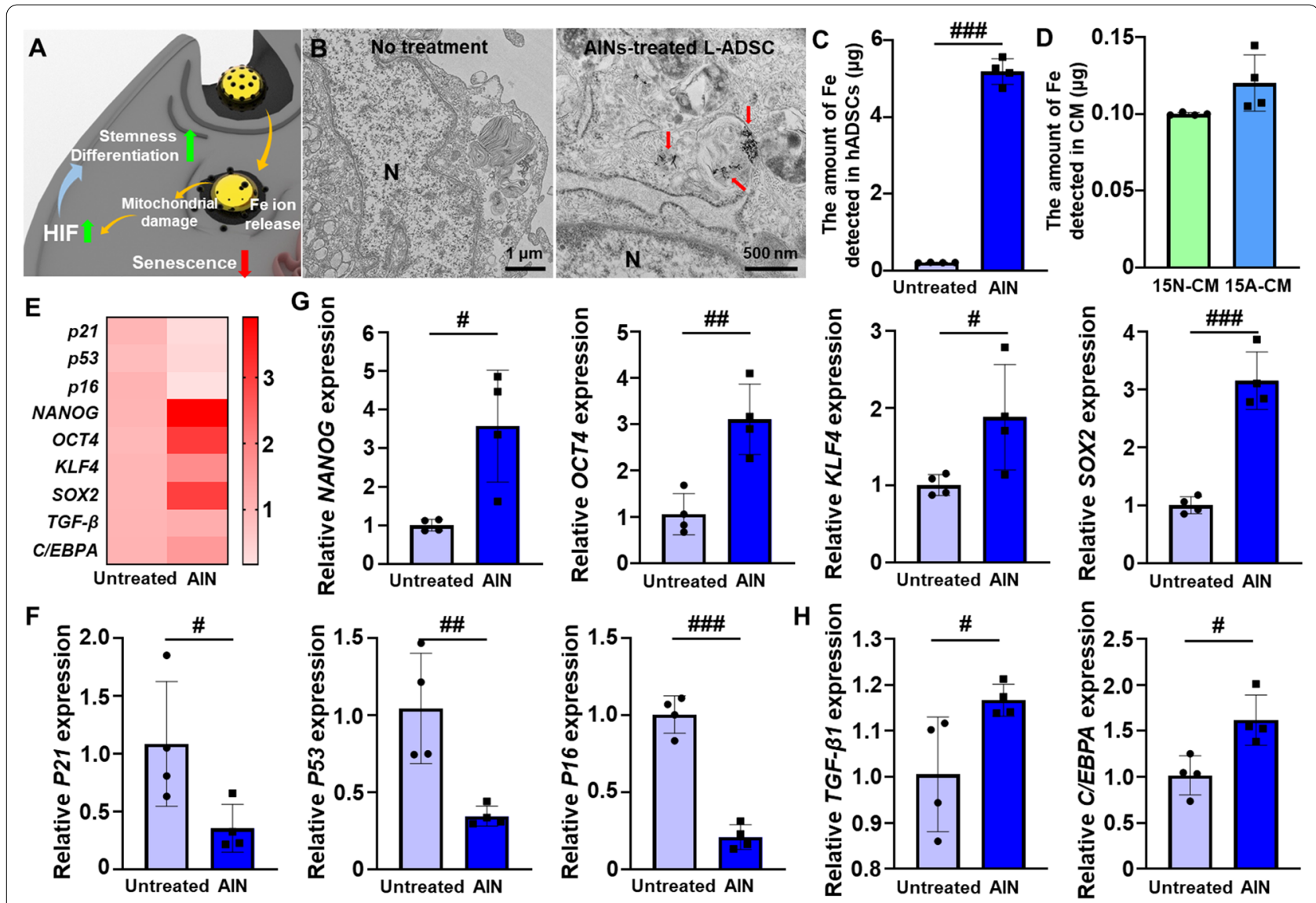

Fig. 3 Cellular uptake and effects of AINs in L-ADSCs. A Schematic representation of the functionality-restoring effects of AINs. B TEM images of L-ADSCs after treatment with AINs for $12 \mathrm{~h}$ (N: nucleus, red arrow: intracellular AINs). C Mass detection of iron in L-ADSCs with or without AIN treatment as quantified using inductively coupled plasma optical emission spectrometer (ICP-OES; $n=4)$. D Mass detection of iron ions in CM harvested from L-ADSCs at passage 15 without AIN treatment (15 N-CM) and from L-ADSCs at passage 15 with AIN treatment (15 A-CM) as quantified by ICP-OES $(n=4)$. E Heat map image of the expression levels of senescence-related and stemness-related genes. F Relative mRNA expression of the senescence-related genes P21,P53, and P16 in L-ADSCs with or without AINs treatment $(n=4)$. G Relative mRNA expression of the stemness-related genes NANOG, OCT4, KLF4, and SOX2 in L-ADSCs with or without AIN treatment $(n=4)$. H Relative mRNA expression of chondrogenesis-related and adipogenesis-related genes in L-ADSCs with or without AIN treatment $(n=4) .\left({ }^{\#} p<0.05\right.$, $\#<0.01$, and ${ }^{\# \# \#} p<0.001$ versus each group)

were analyzed in CM harvested from S-ADSCs at passage 7 without AIN treatment ( $7 \mathrm{~N}-\mathrm{CM}, 15 \mathrm{~N}-\mathrm{CM}$, and 15 A-CM) using an enzyme-linked immunosorbent assay (ELISA) (Fig. 4A). The concentrations of VEGF and FGF2 in $15 \mathrm{~A}-\mathrm{CM}$ were significantly higher than those in $15 \mathrm{~N}-\mathrm{CM}$, and the concentration in $15 \mathrm{~N}-\mathrm{CM}$ was similar to that in $7 \mathrm{~N}-\mathrm{CM}$. Additionally, the profiles of angiogenesis-related proteins, including TGF- $\beta 1$, endocrine gland-derived vascular endothelial growth factor (EGVEGF), VEGF, and FGF2, indicated that the concentrations of these proteins were higher in $15 \mathrm{~A}-\mathrm{CM}$ than they were in $15 \mathrm{~N}-\mathrm{CM}$ (Fig. 4B). As presented in Fig. 4C, the gene expression of $\mathrm{C}-\mathrm{X}-\mathrm{C}$ motif chemokine 12 (CXCL-12) that is related to cell migration was markedly increased in L-ADSCs that were treated with AINs compared to levels in the untreated L-ADSCs. As senescence is known to decrease cell migration ability [44], we performed scratch wound assays using $7 \mathrm{~N}-\mathrm{CM}, 15 \mathrm{~N}-\mathrm{CM}$, and $15 \mathrm{~A}-\mathrm{CM}$ treatments in hADSCs (Fig. 4D). The 15 A-CM significantly enhanced the migration of hADSCs in a manner that was similar to that of $7 \mathrm{~N}-\mathrm{CM}$.

\section{Enhanced therapeutic ability of $15 \mathrm{~A}-\mathrm{CM}$}

To verify the therapeutic efficacy of $\mathrm{CM}$, the closed wound sizes, degrees of regenerated muscle, and complete formation of dermis and epidermis were evaluated at $14 \mathrm{~d}$ after surgery. Each CM was injected at a volume of $200 \mu \mathrm{L}$ daily for the initial $4 \mathrm{~d}$ period. At $11 \mathrm{~d}$ after the last $\mathrm{CM}$ injection, the wounds of the $7 \mathrm{~N}-\mathrm{CM}$ - and $15 \mathrm{~A}-\mathrm{CM}$-injected groups were healed by approximately 
A

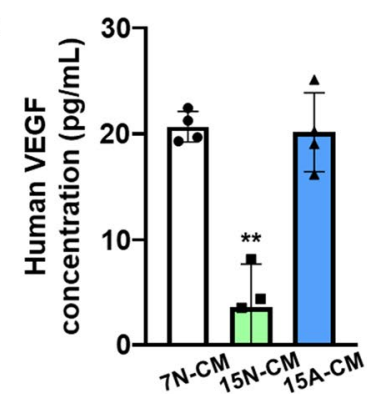

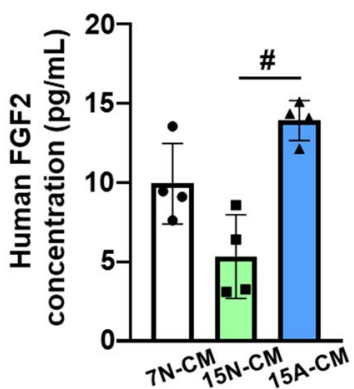

D Day 0

C
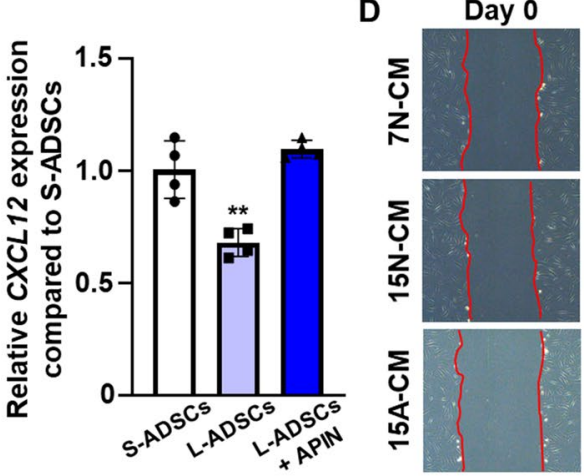

Day 1

B

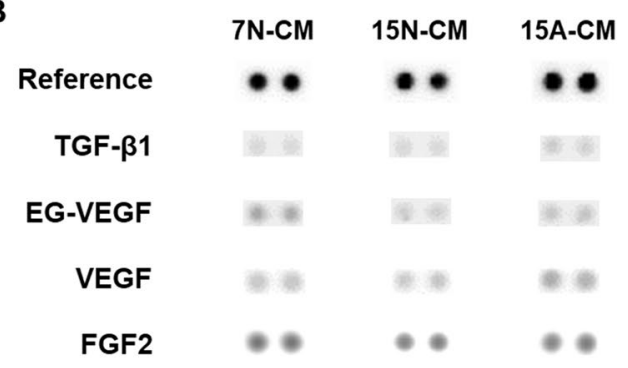

Day 2
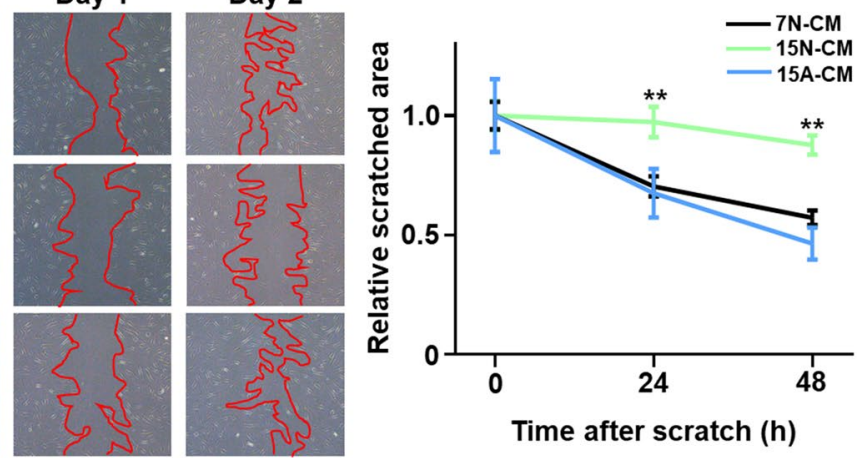

Fig. 4 Enhanced angiogenic potency of AINs-treated L-ADSCS. A Quantification of human VEGF and FGF2 protein secretion within CM harvested from S-ADSCS at passage 7 without AIN treatment ( $7 \mathrm{~N}-\mathrm{CM}, 15 \mathrm{~N}-\mathrm{CM}$, and $15 \mathrm{~A}-\mathrm{CM}$ ) as evaluated using enzyme-linked immunosorbent assay (ELISA $n=4,{ }^{* *} p<0.01$ versus no treatment group, ${ }^{*} p<0.01$ versus each group). B Representative profiles of angiogenesis-related proteins secreted from $7 \mathrm{~N}-\mathrm{CM}, 15 \mathrm{~N}-\mathrm{CM}$, and $15 \mathrm{~A}-\mathrm{CM}$ as evaluated using a human angiogenesis antibody array. C Relative mRNA expression of CXCL12 in S-ADSCs and in L-ADSCs with or without AINs treatment. as quantified using qRT-PCR after treatment with AINs for $12 \mathrm{~h}\left(\mathrm{n}=4,{ }^{*} p<0.01\right.$ versus no treatment group). D Representative images of scratched area and relative cell migration area after treatment with $7 \mathrm{~N}-\mathrm{CM}, 15 \mathrm{~N}-\mathrm{CM}$, and $15 \mathrm{~A}-\mathrm{CM}$ as analyzed using a scratch wound assay (red area indicates the scratched area, $n=4,{ }^{* *} p<0.01$ versus no treatment group)

99\% compared to the size initial wound area, while the wounds of the $15 \mathrm{~N}-\mathrm{CM}$-injected group were healed by approximately $88 \%$ (Fig. 5A). The degree of regenerated muscle was evaluated by measuring the distance between the edges of the defect. The distance between regenerated muscles for the $15 \mathrm{~A}$-CM-injected group was approximately 3,417 $\mu \mathrm{m}$ on an average, and this was significantly shorter compared to that of the $15 \mathrm{~N}-\mathrm{CM}$-injected group (Fig. 5B). Hematoxylin and eosin (H\&E) staining and Masson's trichrome (MT) staining of skin tissue at day 14 revealed complete formation of dermis and epidermis with reduced fibrosis and inflammation in the $15 \mathrm{~A}-\mathrm{CM}$ injected group (Fig. 5C and D). The $15 \mathrm{~N}$-CM-injected group clearly exhibited less of dermis and epidermis formation and a greater degree of fibrosis and inflammation compared to these values in the $7 \mathrm{~N}-\mathrm{CM}$ - and $15 \mathrm{~A}-\mathrm{CM}$ injected groups.

To determine the extent of angiogenesis and dermal regeneration within the wound tissues, blood vessels and dermal formation-related markers in the defect areas were analyzed using qRT-PCR and immunostaining. The $15 \mathrm{~A}-\mathrm{CM}$-injected group expressed $C D 31$ to a greater degree and possessed more distinct microvessels that were immunostained with anti-CD31 antibodies compared to these values in the $15 \mathrm{~N}$-CM-injected group (Fig. 6A). Similar to the observations regarding CD31, the 15 A-CM-injected group exhibited significantly higher gene expression and more obvious detection of laminin and involucrin (major protein components of the dermis and substrate protein, respectively) within the keratinocytes of the epidermis (Fig. 6B and C).

\section{Conclusions}

In the present study, we designed a novel anti-senescence nanomaterial that can respond to low $\mathrm{pH}$ conditions and release iron ions in an intracellular manner to recover the therapeutic properties of L-ADSCs. Iron ions released from AINs in response to the low $\mathrm{pH}$ condition present within the endosomes induce mild ROS generation in L-ADSCs and upregulate HIF-related pathways that can enhance angiogenic paracrine factor secretion. Interestingly, L-ADSCs treated with AINs exhibited downregulated senescence-related gene expression and upregulated stemness- and differentiation-related gene expression without the occurrence of extracellular iron leakage. The secretion of angiogenic paracrine factors by 


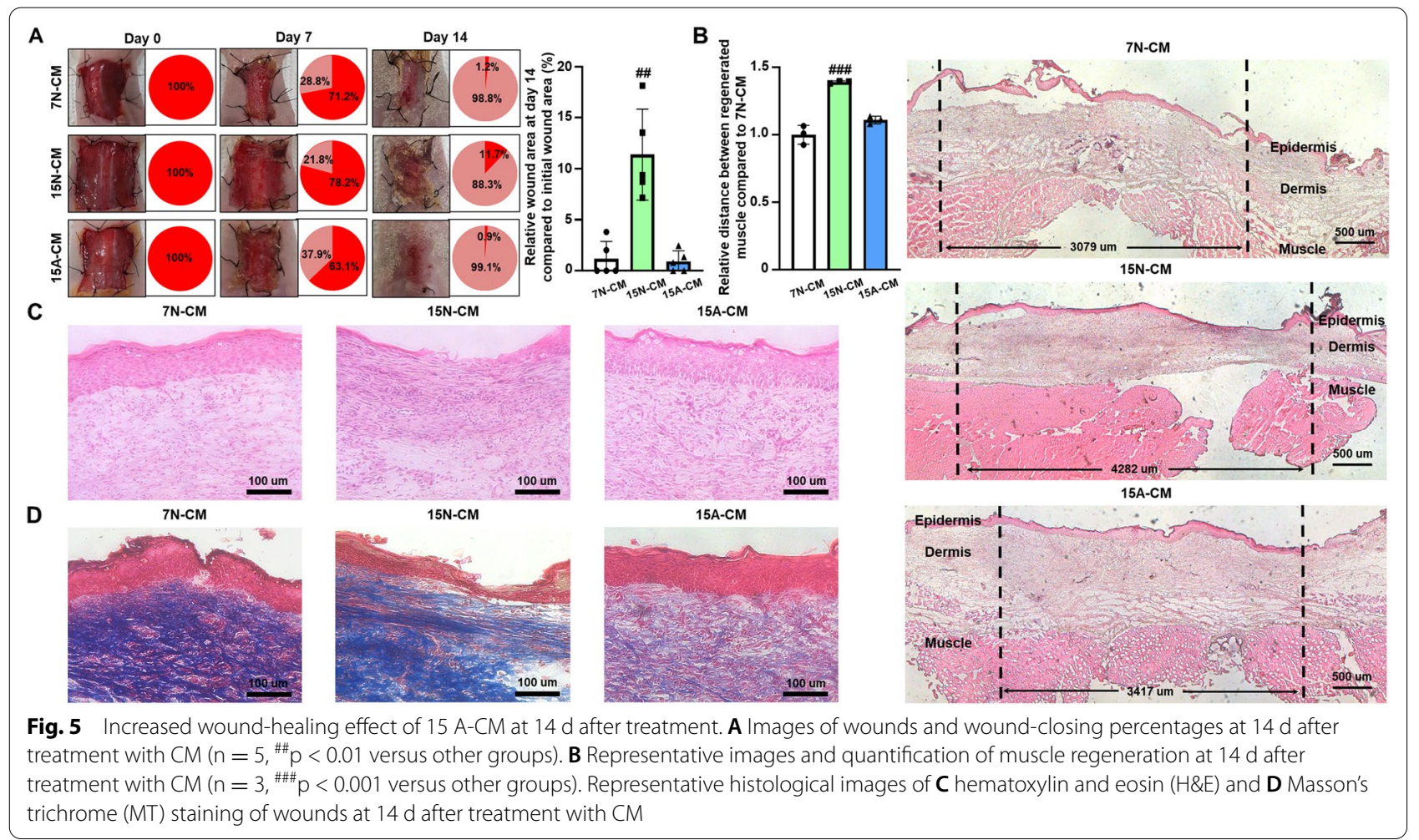

L-ADSCs treated with AINs was significantly enhanced to levels that were similar to those observed in S-ADSCs. As a result of the enhanced secretion of angiogenic paracrine factors, CM harvested from L-ADSCs that were treated with AINs displayed drastically enhanced therapeutic results compared to those observed in response to $\mathrm{CM}$ harvested from conventional L-ADSCs. Consequently, L-ADSCs that were previously considered to be of no use can now be utilized based on treatment of these cells with AINs. Thus, the AINs described in this study may serve as a safe, economical, and progressive strategy for promoting stem cell-based therapy and senescence studies.

\section{Methods}

\section{Materials}

All materials used for the synthesis of AIN, including polyvinylpyrrolidone (PVP), $\mathrm{NaBH}_{4}, \mathrm{HAuCl}_{4} \cdot \mathrm{xH}_{2} \mathrm{O}$ (99.995\%), and $\mathrm{FeCl}_{3}(98 \%)$, were purchased from SigmaAldrich (St. Louis, MO, USA).

\section{Synthesis of AINs}

To synthesize AINs, a PVP solution ( $9 \mathrm{~mL}$ of deionized [DI] water $+100 \mathrm{mg}$ of PVP) was prepared one day prior to synthesis under magnetic stirring $(600 \mathrm{rpm})$ at approximately $25{ }^{\circ} \mathrm{C}$. Prior to synthesis, $4 \mathrm{mg}$ of $\mathrm{NaBH}_{4}, 2 \mathrm{mg}$ of $\mathrm{FeCl}_{3}$ and $4 \mathrm{mg}$ of $\mathrm{HAuCl}_{4} \cdot \mathrm{xH}_{2} \mathrm{O}$, were dissolved in 1
$\mathrm{mL}$ of DI water. Subsequently, $1 \mathrm{~mL}$ of $\mathrm{NaBH}_{4}$ solution was added to $9 \mathrm{~mL}$ of the previously prepared PVP solution and stirred at $600 \mathrm{rpm}$ and at approximately $25^{\circ} \mathrm{C}$ for $10 \mathrm{~min}$. Thereafter, the prepared $\mathrm{FeCl}_{3}(1 \mathrm{~mL})$ and $\mathrm{HAuCl}_{4} \cdot \mathrm{xH}_{2} \mathrm{O}$ solutions $(1 \mathrm{~mL})$ were injected drop-wise using a micro pipette into the reaction solution. The solution $(12 \mathrm{~mL})$ was allowed to react under magnetic stirring $(600 \mathrm{rpm})$ at approximately $25{ }^{\circ} \mathrm{C}$ for an additional $15 \mathrm{~min}$. The reacted solution was subjected to centrifugation $(8000 \mathrm{rpm}, 10 \mathrm{~min})$ to precipitate the AINs, and then washed alternately with DI water and acetone twice. The final AINs were dispersed into $50 \mathrm{~mL}$ of DI water.

\section{Characterization}

An emission electron microscope (JEM-2100 F, JEOL, Tokyo, Japan) was used to obtain TEM and EDXS images $(200 \mathrm{kV})$. The TEM images were analyzed to determine the size distribution of the AINs. An X-ray diffractometer (D-MAX/A, Rigaku, Tokyo, Japan) was used to capture powder XRD patterns at $35 \mathrm{kV}$ and $35 \mathrm{~mA}$. The UV-Vis spectrum in the range of $250-850 \mathrm{~nm}$ was analyzed in a crystal cube using a UV-Vis spectrophotometer (Cary 60 UV-Vis, Agilent Technologies, Santa Clara, CA, USA). The elemental amounts of gold and iron were directly measured using an inductively coupled plasma (ICP) spectrometer (Direct Reading Echelle ICP, Teledyne Leeman Labs, Hudson, NH, USA). 


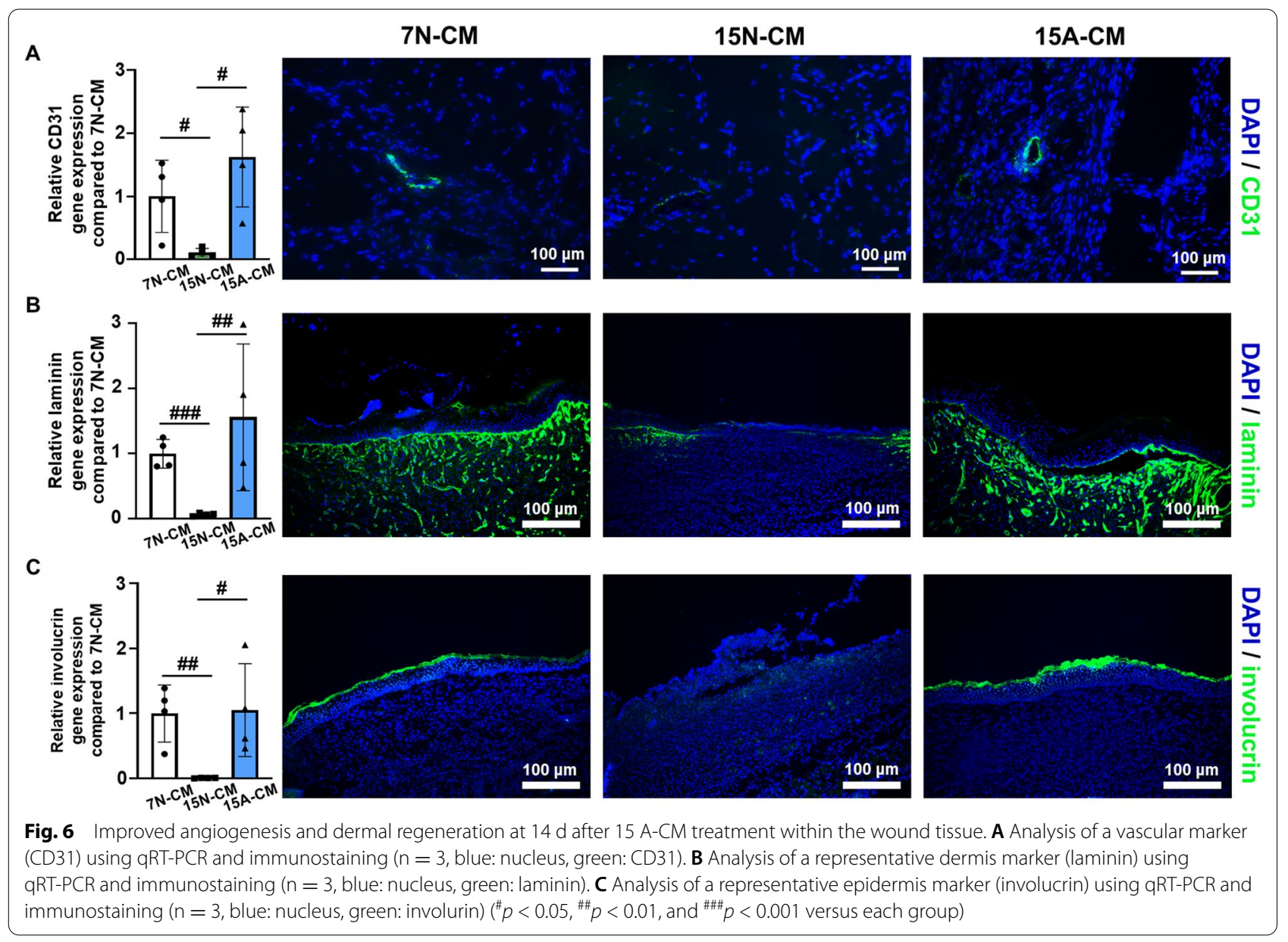

\section{Fe ion leakage from acid-treated AINs used to mimic} endosome conditions

A pH of 4.5 was selected to assess Fe ion release from AINs [19]. The AINs were exposed to different $\mathrm{pH}$ conditions ( $\mathrm{pH} 4.5$ and 7.0) and dispersed in phosphate-buffered saline solution (PBS; Gibco BRL, Gaithersburg, MD, USA) that was adjusted using hydrochloric acid $(\mathrm{HCl}$ $37 \%$, Sigma-Aldrich). The AINs were exposed for $12 \mathrm{~h}$, as this time point was similar to that used for the angiogenic gene expression data. The remaining AINs in PBS were extracted by centrifugation $(8000 \mathrm{rpm}, 10 \mathrm{~min})$. The amount of $\mathrm{Fe}$ ions that was released from the AINs was determined using a UV-Vis spectrophotometer and an ICP spectrometer by analyzing the altered $\mathrm{Au} / \mathrm{Fe}$ ratio in the AINs.

\section{hADSC culture}

hADSCs were purchased from Lonza (Bazel, Switzerland) and cultured in Dulbecco's Modified Eagle's Medium (DMEM; Gibco BRL) supplemented with 10\% (v/v) fetal bovine serum (Gibco BRL), and $1 \%(\mathrm{v} / \mathrm{v})$ penicillin/ streptomycin (Gibco BRL). The cells were cultured at $37{ }^{\circ} \mathrm{C}$ in a humidified incubator with $5 \%(\mathrm{v} / \mathrm{v}) \mathrm{CO}_{2}$. The medium was changed every $2 \mathrm{~d}$. To treat the hADSCs with AINs, a serum-free medium was used to eliminate potential disturbance in the surface charges of the AINs that can be affected by the proteins in the serum [45].

\section{Cell viability}

Cell viability was determined using the CCK- 8 assay (Dojindo Molecular Technologies Inc., Rockville, MD, USA) that measures the amount of formazan dye that is reduced by the intracellular dehydrogenase activity. The number of living cells is proportional to the amount of formazan dye. Briefly, h-ADSCs $\left(1 \times 10^{4}\right.$ cells/well $)$ were cultured for $24 \mathrm{~h}$ in 24-well plates with various concentrations of AINs, and this was followed by three consecutive washes using PBS. The CCK- 8 solution was mixed with fresh serum-free medium and added into each well. After $2 \mathrm{~h}$ of incubation, the samples were measured using a plate reader (Infinite F50, Tecan, Zurich, Switzerland) at an absorbance of $450 \mathrm{~nm}$. Cell viability was calculated as the percentage of the viable cells in the groups treated 
with AINs relative to that in the untreated groups $(n=4$ per group).

\section{Cell morphology}

Cell morphology was evaluated using 1,1'-dioctadecyl3,3,3', $3^{\prime}$-tetramethylindocarbocyanine perchlorate (DiI; Thermo Fisher Scientific, Waltham, MA, USA) staining. After treating the cells with various concentrations of AINs for $24 \mathrm{~h}$, the cells were incubated for $2 \mathrm{~h}$ at $37^{\circ} \mathrm{C}$ with DiI $(6.25 \mu \mathrm{M})$ and then washed twice with PBS. The cells were fixed with $4 \%$ paraformaldehyde solution for 10 min and washed again with PBS. After 4,6-diamidino2-phenylindole (DAPI; Thermo Fisher Scientific) staining, DiI fluorescence was measured using a fluorescence microscope (DMi8, Leica, Wetzlar, Germany).

\section{Terminal deoxynucleotidyl transferase dUTP nick end labeling assay}

To observe the apoptotic activity of L-ADSCs that were treated with AINs for $24 \mathrm{~h}$, the Fluorescein in situ Apoptosis Detection Kit (Merck Millipore, Darmstadt, Germany) was used according to the manufacturer's instructions. The final fluorescence images were captured using a fluorescence microscope (DMi8).

\section{Harvest of CM}

hADSCs $\left(1.6 \times 10^{6}\right.$ cells $)$ were seeded into a $150 \mathrm{~mm}$ cell culture plate (Corning Inc., Corning, New York, NY, USA) and incubated overnight. The medium was replaced with medium containing AINs after incubation for $24 \mathrm{~h}$, and the cells were then incubated for an additional $12 \mathrm{~h}$. After incubation, the cells were washed three times with PBS and cultured for $2 \mathrm{~d}$ in serum-free DMEM. To remove any remaining cell fragments and contaminants, the harvested CM was subjected to centrifugation (1500 rpm, $5 \mathrm{~min}$ ) and filtration.

\section{Cellular uptake and leakage of AINs}

Cellular uptake and leakage of AINs in L-ADSCs $\left(1.0 \times 10^{5}\right.$ cells $)$ were analyzed by quantifying the amount of gold and iron ions within the cells and CM. After uptake of AINs (12 h), the cells were washed and lysed in nitric acid hydrochloride (a mixture of nitric acid and hydrochloric acid in a molar ratio of 1:3) to dissolve all of the components, including AINs. Ionized samples were diluted in DI water $(1: 4[\mathrm{v} / \mathrm{v}])$. The gold and iron concentrations were determined using an ICP-OES (Varian, Palo Alto, CA, USA). To observe the uptake of AINs, L-ADSCs were seeded into a 6-well plate and incubated with AINs. Ultrathin sections of the cells were analyzed using TEM (Talos L120C, Thermo Fisher Scientific) at $120 \mathrm{kV}$ to observe the distribution of AINs. Briefly, AIN-treated cells were washed three times with PBS to eliminate the unbound AINs. The cells were treated with trypsin, washed again three times with PBS, and fixed with Karnovsky's fixative (5\% glutaraldehyde [SigmaAldrich] $+4 \%$ formaldehyde in $0.1 \mathrm{M}$ cacodylate buffer

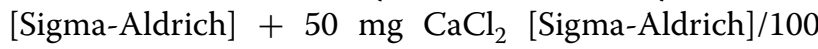
$\mathrm{mL} \mathrm{H}_{2} \mathrm{O}$ ) for $2 \mathrm{~h}$. The fixed cells were washed three times with $0.05 \mathrm{M}$ sodium cacodylate buffer. Post-fixation staining was performed using $2 \%$ osmium tetroxide (Sigma-Aldrich) in $0.1 \mathrm{M}$ cacodylate buffer for $2 \mathrm{~h}$ at $4{ }^{\circ} \mathrm{C}$. The samples were dehydrated in alcohol (30\%, 50\%, 70\%, $80 \%, 90 \%$, and $100 \%$ ethanol), treated twice with propylene oxide (Sigma-Aldrich) for $10 \mathrm{~min}$, and then treated with propylene oxide and Spurr low-viscosity resin for $2 \mathrm{~h}$. The samples were further treated for $24 \mathrm{~h}$ with pure resin and then embedded in molds. The resin blocks were polymerized at $70{ }^{\circ} \mathrm{C}$ for $2 \mathrm{~d}$ and then cut into ultrathin sections $(70 \mathrm{~nm})$ using an ultramicrotome (Reichert-Jung Ultracut E, Leica). The sections were stained with $1 \%$ lead citrate and $0.5 \%$ uranyl acetate and then analyzed. Cellular uptake time was determined based on the gene expression results.

\section{Quantitative reverse transcription polymerase chain reaction}

qRT-PCR was used to quantify the relative expression levels of genes encoding glyceraldehyde 3-phosphate dehydrogenase (GAPDH), VEGF, FGF2, Bcl-2-associated X protein $(B A X)$, caspase3, ki-67, proliferating cell nuclear antigen (PCNA), P21, P53, P16, NANOG, octamerbinding transcription factor 4 (OCT4), kruppel-like factor 4 (KLF4), SOX2, C-X-C chemokine receptor type 4 (CXCR4), $\beta$-actin, cluster of differentiation 31 (CD31), laminin, and involucrin. The samples were lysed in TRI$\mathrm{zol}^{\mathrm{TM}}$ reagent (Invitrogen, Carlsbad, CA, USA), and total RNA was extracted with chloroform and precipitated with isopropanol. After the supernatant was removed, the RNA pellet was washed with $75 \%(\mathrm{v} / \mathrm{v})$ ethanol, airdried, and dissolved in $0.1 \%(\mathrm{v} / \mathrm{v})$ diethyl pyrocarbonate (DEPC)-treated water. For qRT-PCR, the SsoAdvanced ${ }^{\mathrm{TM}}$ Universal SYBR Green Supermix Kit (Bio-Rad, Hercules, CA, USA) and the CFX Connect ${ }^{\mathrm{TM}}$ real-time PCR Detection System (Bio-Rad) were used. The primers used for qRT-PCR are listed in Table 1.

\section{CM component analysis}

The protein components of $7 \mathrm{~N}-\mathrm{CM}, 15 \mathrm{~N}-\mathrm{CM}$, and 15 A-CM were identified using a man angiogenesis array kit (R\&D Systems, Inc., Minneapolis, MN, USA). One mL of $\mathrm{CM}$ was loaded onto the human angiogenesis array kit. After blocking the array membrane with blocking buffer for $1 \mathrm{~h}$ and subsequent membrane washing, each $\mathrm{CM}$ and array detection antibody cocktail was mixed and added to the blocked membrane. This was followed by 
Table 1 Sequences of qRT-PCR primers

\begin{tabular}{|c|c|c|}
\hline Primer & Sequence & \\
\hline \multirow{2}{*}{$\begin{array}{l}\text { Human } \\
\text { GAPDH }\end{array}$} & Forward & 5'-GTC GGA GTC AAC GGA TTT GG-3' \\
\hline & Reverse & 5'-GGG TGG AAT CAA TTG GAA CAT-3' \\
\hline \multirow{2}{*}{$\begin{array}{l}\text { Human } \\
\text { VEGF }\end{array}$} & Forward & 5'-GAG GGC AGA ATC ATC ACG AAG T-3' \\
\hline & Reverse & 5'-CAC CAG GGT CTC GATTGG AT-3' \\
\hline \multirow{2}{*}{$\begin{array}{l}\text { Human } \\
\text { FGF2 }\end{array}$} & Forward & 5'-GAC GGC AGA GTT GAC GG-3' \\
\hline & Reverse & 5'-CTC TCT CTT CTG CTT GAA GTT-3' \\
\hline \multirow{2}{*}{$\begin{array}{l}\text { Human } \\
\text { BAX }\end{array}$} & Forward & 5'-GCA ACT TCA ACT GGG GCC GGG-3' \\
\hline & Reverse & 5'- GAT CCA GCC CAA CAG CCG CTC-3' \\
\hline \multirow{2}{*}{$\begin{array}{l}\text { Human } \\
\text { CASPASE3 }\end{array}$} & Forward & 5'-CCT GGTTAT TAT TCT TGG CGA AA-3' \\
\hline & Reverse & $5^{\prime}-\mathrm{GCA}$ CAA AGC GAC TGG ATG AA-3' \\
\hline \multirow{2}{*}{$\begin{array}{l}\text { Human } \\
\text { Kl-67 }\end{array}$} & Forward & 5'-CCA CAC TGT GTC GTC GTT TG-3' \\
\hline & Reverse & 5'-CCG TGC GCTTAT CCA TTC A-3' \\
\hline \multirow{2}{*}{$\begin{array}{l}\text { Human } \\
\text { PCNA }\end{array}$} & Forward & 5'-CCT GCT GGG ATA TTA GCT CCA-3' \\
\hline & Reverse & $5^{\prime}-$ CAG CGG TAG GTG TCG AAG C-3' \\
\hline \multirow{2}{*}{$\begin{array}{l}\text { Human } \\
\text { P21 }\end{array}$} & Forward & 5'-TGA GCC GCG ACT GTG ATG-3' \\
\hline & Reverse & 5'-GTC TCG GTG ACA AAG TCG AAG TT-3' \\
\hline \multirow{2}{*}{$\begin{array}{l}\text { Human } \\
\text { P53 }\end{array}$} & Forward & 5'-CCT CAG CAT CTT ATC CGA GTG G-3' \\
\hline & Reverse & 5'-TGG ATG GTG GTA CAG TCA GAG C-3' \\
\hline \multirow{2}{*}{$\begin{array}{l}\text { Human } \\
\text { P16 }\end{array}$} & Forward & 5'-ACT TCA GGG GTG CCA CAT TC-3' \\
\hline & Reverse & 5'-CGA CCC TGT CCC TCA AAT CC-3' \\
\hline \multirow{2}{*}{$\begin{array}{l}\text { Human } \\
\text { NANOG }\end{array}$} & Forward & 5'-AGT CCC AAA GGC AAA CAA CCC ACT TC-3' \\
\hline & Reverse & 5'-TGC TGG AGG CTG AGG TAT TTC TGT CTC-3' \\
\hline \multirow{2}{*}{$\begin{array}{l}\text { Human } \\
\text { OCT4 }\end{array}$} & Forward & 5'-CTG GGTTGA TCC TCG GAC CT-3' \\
\hline & Reverse & $5^{\prime}-C A C$ AGA ACT CAT ACG GCG GG -3' \\
\hline \multirow{2}{*}{$\begin{array}{l}\text { Human } \\
\text { KLF4 }\end{array}$} & Forward & 5'-TCT CAA GGC AGA CCT GCG AA-3' \\
\hline & Reverse & 5'-TAG TGC CTG GTC AGTTCA TC-3' \\
\hline \multirow{2}{*}{$\begin{array}{l}\text { Human } \\
\text { SOX2 }\end{array}$} & Forward & 5'-TGA TGG AGA CGG AGC TGA A-3' \\
\hline & Reverse & 5'-GGG CTG TTTTTC TGG TTG C-3' \\
\hline \multirow{2}{*}{$\begin{array}{l}\text { Human } \\
\text { TGF- } \beta 1\end{array}$} & Forward & 5'-CCC AGC ATC TGC AAA GCT C-3' \\
\hline & Reverse & 5'-GTC AAT GTA CAG CTG CCG CA-3' \\
\hline \multirow{2}{*}{$\begin{array}{l}\text { Human } \\
\text { C/EBPA }\end{array}$} & Forward & 5'-TTG TGC CTT GGA AAT GCA AAC-3' \\
\hline & Reverse & 5'-TCG GGA AGG AGG CAG GAA AC-3' \\
\hline \multirow{2}{*}{$\begin{array}{l}\text { Human } \\
\text { CXCR12 }\end{array}$} & Forward & 5'-TGC CAG AGC CAA CGT CAA G-3' \\
\hline & Reverse & 5'-CAG CCG GGC TAC AAT CTG AA-3' \\
\hline \multirow{2}{*}{$\begin{array}{l}\text { Mouse } \\
\beta \text {-actin }\end{array}$} & Forward & 5'-GGC TGT ATT CCC CTC CAT CG-3' \\
\hline & Reverse & 5'-CCA GTT GGT AAC AAT GCC ATG T-3' \\
\hline \multirow{2}{*}{$\begin{array}{l}\text { Mouse } \\
\text { CD31 }\end{array}$} & Forward & 5'-CAA ACA GAA ACC CGT GGA GAT G-3' \\
\hline & Reverse & 5'-ACC GTA ATG GCT GTT GGC TTC-3' \\
\hline \multirow{2}{*}{$\begin{array}{l}\text { Mouse } \\
\text { Laminin }\end{array}$} & Forward & 5'-GGA CGG GAA TTC CGTTAG GG-3' \\
\hline & Reverse & 5'-CAG GTC CAA GGA CTG CAC TT-3' \\
\hline \multirow{2}{*}{$\begin{array}{l}\text { Mouse } \\
\text { Involucrin }\end{array}$} & Forward & 5'-CCT GTG AGT TTG TTT GGT CTA CA-3' \\
\hline & Reverse & 5'-GAA CCA CAG CTG GAA CAG TC-3' \\
\hline
\end{tabular}

overnight incubation at $4{ }^{\circ} \mathrm{C}$ with shaking. After washing, streptavidin-horseradish peroxidase (HRP) buffer was added to the membrane, and the membrane was incubated for $30 \mathrm{~min}$. Following another wash, Chemi Reagent Mixture was added to the membrane for reaction at room temperature, and the signal was measured using the LAS-3000 system (Fujifilm, Tokyo, Japan).

\section{Cell migration}

To evaluate the migration ability of each CM, hADSCs $\left(1 \times 10^{5}\right.$ cells) were seeded into 6 -well cell culture dishes (Corning Inc.). The cells were incubated for $24 \mathrm{~h}$ and then scratched. The migration area was measured at 0,12 , and $24 \mathrm{~h}$ after scratching. The relative migration area was calculated based on comparison to the initial scratch areas.

\section{Mouse skin wound model}

Four-week-old female athymic mice (BALB/c-nu, 20-25 g body weight; Orient, Seongnam, Gyeonggi, Korea) were anesthetized with xylazine $(10 \mathrm{mg} / \mathrm{kg}$, Bayer, Seoul, Korea) and ketamine $(100 \mathrm{mg} / \mathrm{kg}$, Yuhan, Seoul, Korea). Each group included six, randomly selected mice. The full-thickness skin was excised in a square shape $(2 \times 2 \mathrm{~cm})$ and ligated using a 6-0 silk suture (AILEE, Busan, Korea) at two sites on each border. CM $(200 \mu \mathrm{L})$ was injected into the muscles on each side using the same volume every day for the initial $4 \mathrm{~d}$ period. Based on this, $800 \mu \mathrm{L}$ of $\mathrm{CM}$ was injected into each mouse. The wound was covered with sterile gauze after the $\mathrm{CM}$ injections. The wound-covering films were changed at 3,7 , and $10 \mathrm{~d}$ to acquire photographs of the wounds. All animals were sacrificed at $14 \mathrm{~d}$ after anesthesia to harvest the wound tissue. All animal treatments and experimental procedures were approved by the Institutional Animal Care and Use Committee of Sungkyunkwan University (no. SKKUIACUC2017-05-03).

\section{Histological examination}

The wound tissue that was retrieved at $14 \mathrm{~d}$ post-surgery was embedded in optimal cutting temperature compound (SciGen Scientific Inc., Gardenas, California, USA). The samples were frozen at $-20{ }^{\circ} \mathrm{C}$ and sliced into $10 \mu \mathrm{m}$-thick sections using a microtome (Cryostat, Leica). The sliced samples were stained with H\&E to verify tissue regeneration and with MT staining to assess inflammation.

\section{Immunohistochemistry}

The sliced samples were stained with primary antibodies targeting anti-CD31, anti-laminin, and anti-involucrin antibodies (Abcam, Cambridge, UK). After staining with the primary antibodies, fluorescein isothiocyanate-conjugated anti-rabbit antibodies (Jackson ImmunoResearch Laboratories, West Grove, PA, USA) were used to detect the signals. The immunohistochemically stained samples were counterstained with DAPI, and the images were obtained using a fluorescence microscope (DMi8). 


\section{Statistical analyses}

All quantitative data are expressed as mean \pm standard deviation. For statistical analysis, one-way analysis of variance was performed with the Bonferroni correction using SigmaPlot (version 12.5, Systat software, San Jose, CA, USA). Statistical significance was set at $p<0.05$. and Technology, Hwarang-ro 14-gil 5, Seoungbuk-gu, Seoul 02792, Republic of Korea. ${ }^{4}$ Division of Bio-Medical Science \& Technology, University of Science and Technology, 113 Gwahangno, Yuseong-gu, Daejeon 305-333, Republic of Korea.

Received: 16 July 2021 Accepted: 20 October 2021

Published online: 30 October 2021

\section{Abbreviations}

AIN: Anti-senescence ion-delivering nanocarrier; AuNP: Gold nanoparticle; CCK-8: Cell Counting Kit-8; CM: Conditioned media; EDXS: Energy-dispersive X-ray spectroscopy; ELISA: Enzyme-linked immunosorbent assay; FDA/EB: Fluorescein diacetate/ethidium; FGF: Fibroblast growth factor; hADSC: Human adipose-derived stem cell; HIF: Hypoxia-inducible factor; H\&E: Hematoxylin and eosin; ICP-OES: Inductively coupled plasma optical emissionspectrometer; L-ADSCs: Long-term-cultured hADSCs; MT: Masson's trichrome; ROS: Reactive oxygen species; S-ADSCs: Short-term-cultured hADSCs; TEM:Transmission electron microscopy; TUNEL: Terminal deoxynucleotidyl transferase-mediated dUTPnick end labeling; UV-Vis: Ultraviolet-visible spectroscopy; VEGF: Vascular endothelial growth factor; XRD: X-ray diffraction.

\section{Supplementary Information}

The online version contains supplementary material available at https://doi. org/10.1186/s12951-021-01098-7.

Additional file 1. TEM images of hADSCs after AINs treatment for $12 \mathrm{~h}$ shown as stepwise magnification ( $\mathrm{N}$ : nucleus, red arrows indicate AINs in a cell).

\section{Acknowledgements}

We would like to thank Editage (www.editage.co.kr) for English language editing.

\section{Authors' contributions}

This study was conceptualized by YHK, GBI, TY, and SHB. Nanocarriers were synthesized and characterized by TY. In vitro stem cell experiments were performed by YHK. In vivo wound modeling and analyses were performed by YHK, GBI, SWK, and YJK. The original draft was written by YHK and GBI. All authors discussed the data and reviewed the manuscript. All authors read and approved the final manuscript.

\section{Funding}

This work was supported by the National Research Foundation of Korea (NRF) and the Ministry of Science and ICT (MSIT) (2019R1C1C1007384, and 2018M3A9E2023255). This research was also supported by the Korea Medical Device Development Fund grant funded by the Korea government (the Ministry of Science and ICT, the Ministry of Trade, Industry and Energy, the Ministry of Health \&Welfare, and the Ministry of Food and Drug Safety, Republic of Korea, Project Number: 202011B31). This work is partially funded by a grant from the Basic Science Research Program through the National Research Foundation of Korea funded by the Ministry of Science, ICT, and Future Planning (Grant No. 2019R1A2C2002390). This work was supported by the National Research Foundation of Korea (NRF) grant funded by the Korea government (MSIT) (No. 2021R1A4A1032782).

\section{Declarations}

\section{Competing interests}

The authors declare that they have no competing interests.

\section{Author details}

${ }^{1}$ School of Chemical Engineering, Sungkyunkwan University, Suwon 440-746, Republic of Korea. ${ }^{2}$ Department of Chemical Engineering, College of Engineering, Kyung Hee University, Yongin 17104, Republic of Korea. ${ }^{3}$ Center for Biomaterials, Biomedical Research Institute, Korea Institute of Science

\section{References}

1. Michira D, Hubenak JR, Mathur AB. Nanoparticle systems as tools to improve drug delivery and therapeutic efficacy. J Biomed Mater Res Part A. 2013;101(12):3646-60.

2. Chee HL, Gan CRR, Ng M, Low L, Fernig DG, Bhakoo KK, Paramelle D. Biocompatible peptide-coated ultrasmall superparamagnetic iron oxide nanoparticles for in vivo contrast-enhanced magnetic resonance imaging. ACS Nano. 2018;12(7):6480-91.

3. Kaushik M, Niranjan R, Thangam R, Madhan B, Pandiyarasan V, Ramachandran C, Oh DH, Venkatasubbu D. Investigations on the antimicrobial activity and wound healing potential of $\mathrm{ZnO}$ nanoparticles. Appl Surf Sci. 2019:479:1169-77.

4. Han J, Kim B, Shin JY, Ryu S, Noh M, Woo J, Park JS, Lee Y, Lee N, Hyeon T, Choi D, Kim BS. Iron oxide nanoparticle-mediated development of cellular gap junction crosstalk to improve mesenchymal stem cells' therapeutic efficacy for myocardial infarction. ACS Nano. 2015;9(3):2805-19.

5. Huang X, Zhang F, Wang Y, Sun X, Choi KY, Liu D, Choi TH, Cheon J, Niu G, Chen X. Design considerations of iron-based nanoclusters for noninvasive tracking of mesenchymal stem cell homing. ACS Nano. 2014;8(5):4403-14.

6. LI X, Wei Z, Li B, Li J, Lv H, Wu L, Zhang H, Yang B, Zhu M, Jiang J. In vivo migration of Fe3O4@polydopamine nanoparticle-labeled mesenchymal stem cells to burn injury sites and their therapeutic effects in a rat model. Biomaterials science. 2019;7(7):2861-72.

7. Chen X, Yu C, Kang R, Tang D. Iron metabolism in ferroptosis. Front Cell Dev Biol. 2020;8:590226.

8. Masaldan S, Bush Al, Devos D, Rolland AS, Moreau C. Striking while the iron is hot: Iron metabolism and ferroptosis in neurodegeneration. Free Radic Biol Med. 2019;133:221-33.

9. Cozzi A, Orellana DI, Santambrogio P, Rubio A, Cancellieri C, Giannelli S, Ripamonti M, Taverna S, Lullo GD, Rovida E, Ferrari M, Forni GL, Fiorillo C, Broccoli $V$, Levi. Stem cell modeling of neuroferritinopathy reveals iron as a determinant of senescence and ferroptosis during neuronal aging. Stem Cell Rep. 2019;13(5):832-46.

10. Liu Z, Xia X, Lv X, Song E, Song Y. Iron-bearing nanoparticles trigger human umbilical vein endothelial cells ferroptotic responses by promoting intracellular iron level. Environ Pollut. 2021;287:117345.

11. Lee SJ, Sohn YD, Andukuri A, Kim S, Byun J, Han JW, Park IH, Jun HW, Yoon YS. Enhanced therapeutic and long-term dynamic vascularization effects of human pluripotent stem cell-derived endothelial cells encapsulated in a nanomatrix gel. Circulation. 2017;136(20):1939-54.

12. Peters EB. Endothelial progenitor cells for the vascularization of engineered tissues. Tissue Eng Part B Rev. 2018;24(1):1-24.

13. Nakagami H, Morishita R, Maeda K, Kikuchi Y, Ogihara T, Kaneda Y. Adipose tissue-derived stromal cells as a novel option for regenerative cell therapy. J Atheroscler Thromb. 2006;13(2):77-81.

14. Gimble JM, Katz AJ, Bunnell BA. Adipose-derived stem cells for regenerative medicine. Circ Res. 2007;100(9):1249-60.

15. Kilroy GE, Foster SJ, Wu X, Ruiz J, Sherwood S, Heifetz A, Ludlow JW, Stricker DM, Potiny S, Green P, Halvorsen YC, Cheatham B, Storms RW, Gimble JM. Cytokine profile of human adipose-derived stem cells: expression of angiogenic, hematopoietic, and pro-inflammatory factors. J Cell Physiol. 2007;212(3):702-9.

16. Feisst $\mathrm{V}$, Meidinger $\mathrm{S}$, Locke MB. From bench to bedside: use of human adipose-derived stem cells. Stem Cells Cloning. 2015;8:149.

17. Casiraghi F, Remuzzi G, Abbate M, Perico N. Multipotent mesenchymal stromal cell therapy and risk of malignancies. Stem Cell Rev Rep. 2013:9(1):65-79.

18. Danieli P, Malpasso G, Ciuffreda MC, Cervio E, Calvillo L, Copes F, Pisano F, Mura M, Kleijn L, Boer LA, Viarengo G, Rosti V, Spinillo A, Roccio M, 
Gnecchi M. Conditioned medium from human amniotic mesenchymal stromal cells limits infarct size and enhances angiogenesis. Stem Cells Transl Med. 2015;4(5):448-58.

19. Shen C, Lie P, Miao T, Yu M, Lu Q, Feng T, Li J, Zu T, Liu X, Li H. Conditioned medium from umbilical cord mesenchymal stem cells induces migration and angiogenesis. Mol Med Rep. 2015;12(1):20-30.

20. Ricles LM, Nam SY, Trevino EA, Emelianov SY, Suggs LJ. A dual gold nanoparticle system for mesenchymal stem cell tracking. J Mater Chem B. 2014;2(46):8220-30

21. Yao C, Wang W, Wang P, Zhao M, Li X, Zhang F. Near-infrared upconversion mesoporous cerium oxide hollow biophotocatalyst for concurrent $\mathrm{pH}-/ \mathrm{H} 2 \mathrm{O} 2$-responsive O2-evolving synergetic cancer therapy. Adv Mater. 2018;30(7):1704833

22. Bae M, Lee H, Yoo K, Kim S. Copper (I) selective chemisorption on magnetite (Fe3O4) over gold (I) ions in chloride solution with cyanide. Hydrometallurgy. 2021;201:105560.

23. Zhang $\mathrm{Q}$, Liu P, Zhu Z, Zhang J, Cao F. The study of the $\mathrm{H} 2 \mathrm{O} 2$ during oxygen reduction process on typically corroding metal surface using tip generation-substrate collection mode of SECM. Corros Sci. 2020:164:108312

24. Cui D, Arima M, Hirayama T, Ikeda E. Hypoxia-induced disruption of neural vascular barrier is mediated by the intracellular induction of Fe (II) ion. Exp Cell Res. 2019;379(2):166-71.

25. Pugh CW, Ratcliffe PJ. Regulation of angiogenesis by hypoxia: role of the HIF system. Nat Med. 2003;9(6):677-84.

26. Simon HU, Haj-Yehia A, Levi-Schaffer F. Role of reactive oxygen species (ROS) in apoptosis induction. Apoptosis. 2000;5(5):415-8.

27. Fehrer C, Brunauer R, Laschober G, Unterluggauer H, Reitinger S, Kloss F, Gülly C, Gaßner R, Lepperdinger G. Reduced oxygen tension attenuates differentiation capacity of human mesenchymal stem cells and prolongs their lifespan. Aging cell. 2007:6(6):745-57.

28. Jin Y, Kato T, Furu M, Nasu A, Kajita Y, Mitsui H, Ueda M, Aoyama T, Nakayama T, Nakamura T, Toguchida J. Mesenchymal stem cells cultured under hypoxia escape from senescence via down-regulation of $p 16$ and extracellular signal regulated kinase. Biochem Biophys Res Commun. 2010;391(3):1471-6.

29. Welford SM, Bedogni B, Gradin K, Poellinger L, Powell MB, Giaccia A. J. HIF1a delays premature senescence through the activation of MIF. Genes Dev. 2006;20(24):3366-71

30. Xie S, Wang Q, Luo L, Ruan Q, Liu T, Jhanwar-Uniyal M, Darzynkiewicz Z, Traganos F, Dai W. Proteasome-dependent downregulation of p21Waf1/ Cip1 induced by reactive oxygen species. J Interferon Cytokine Res. 2002;22(9):957-63.

31. Zhou S, Greenberger JS, Epperly MW, Goff JP, Adler C, LeBoff MS, Glowacki J. Age-related intrinsic changes in human bone-marrow-derived mesenchymal stem cells and their differentiation to osteoblasts. Aging Cell. 2008;7(3):335-43.

32. Hong SH, Lee MH, Koo MA, Seon GM, Park YJ, Kim DH, Park JC. Stem cell passage affects directional migration of stem cells in electrotaxis. Stem Cell Res. 2019;38:101475.

33. Roobrouck VD, Ulloa-Montoya F, Verfaillie CM. Self-renewal and differentiation capacity of young and aged stem cells. Exp Cell Res. 2008:314(9):1937-44.
34. Tofino-Vian M, Guillen MI, Perez del Caz MD, Castejon MA, Alcaraz MJ. Extracellular vesicles from adipose-derived mesenchymal stem cells downregulate senescence features in osteoarthritic osteoblasts. Oxid Med Cell Longev. 2017;2017:7197598

35. Villeda SA, et al. The ageing systemic milieu negatively regulates neurogenesis and cognitive function. Nature. 2011;477(7362):90-4.

36. Wahlestedt M, Erlandsson E, Kristiansen T, Lu R, Brakebusch C, Weissman IL, Yuan J, Martin-Gonzalez J, Bryder D. Clonal reversal of ageing-associated stem cell lineage bias via a pluripotent intermediate. Nat Commun. 2017:8(1):1-8.

37. Abad M, Mosteiro L, Pantoja C, Cañamero M, Rayon T, Ors I, Graña O, Megías D, Domínguez O, Martínez D, Manzanares M, Ortega S, Serrano M. Reprogramming in vivo produces teratomas and iPS cells with totipotency features. Nature. 2013;502(7471):340-5.

38. Nguyen HT, Thapa RK, Shin BS, Jeong JH, Kim JR, Yong CS, Kim J. O. CD9 monoclonal antibody-conjugated PEGylated liposomes for targeted delivery of rapamycin in the treatment of cellular senescence. Nanotechnology. 2017;28(9):095101.

39. Chen YJ, Wu SC, Wang HC, Wu TH, Yuan SSF, Lu TT, Liaw WF, Wang YM. Activation of angiogenesis and wound healing in diabetic mice using NO-delivery dinitrosyl iron complexes. Mol Pharm. 2019;16(10):4241-51.

40. Mashayekhi S, Rasoulpoor S, Shabani S, Esmaeilizadeh N, Serati-Nouri H, Sheervalilou R, Pilehvar-Soltanahmadi Y. Curcumin-loaded mesoporous silica nanoparticles/nanofiber composites for supporting long-term proliferation and stemness preservation of adipose-derived stem cells. Int J Pharm. 2020;587:119656.

41. Li Z, Foley IV, Peng JJ, Sun S, Ren CJ, Wiederrecht Y, Gray GP, Sun SK. Y. Reversible modulation of surface plasmons in gold nanoparticles enabled by surface redox chemistry. Angew Chem. 2015;127(31):9076-9.

42. Distler JHW, Jüngel A, Pileckyte M, Zwerina J, Michel BA, Gay RE, Kowal-Bielecka O, Matucci-Cerinic M, Schett G, Marti HH, Gay S, Distler $O$. Hypoxia-induced increase in the production of extracellular matrix proteins in systemic sclerosis. Arthr Rheum. 2007;56(12):4203-15.

43. Yang L, Jiang Y, Wu SF, Zhou MY, Wu YL, Chen G. Q. CCAAT/enhancerbinding protein a antagonizes transcriptional activity of hypoxia-inducible factor 1 a with direct protein-protein interaction. Carcinogenesis. 2008:29(2):291-8.

44. Moujaber O, Fishbein F, Omran N, Liang Y, Colmegna I, Presley JF, Stochaj $\mathrm{U}$. Cellular senescence is associated with reorganization of the microtubule cytoskeleton. Cell Mol Life Sci. 2019;76(6):1169-83.

45. Ferraris S, Cazzola M, Peretti V, Stella B, Spriano S. Zeta potential measurements on solid surfaces for in vitro biomaterials testing: surface charge, reactivity upon contact with fluids and protein absorption. Front Bioeng Biotechnol. 2018;6:60.

\section{Publisher's Note}

Springer Nature remains neutral with regard to jurisdictional claims in published maps and institutional affiliations.

Ready to submit your research? Choose BMC and benefit from:

- fast, convenient online submission

- thorough peer review by experienced researchers in your field

- rapid publication on acceptance

- support for research data, including large and complex data types

- gold Open Access which fosters wider collaboration and increased citations

- maximum visibility for your research: over $100 \mathrm{M}$ website views per year

At BMC, research is always in progress.

Learn more biomedcentral.com/submissions 